\title{
Investigations on Haemato-biochemical Alterations in Buffaloes Affected with Gastrointestinal Tract Atony
}

\author{
Jubin*, Yudhbir Singh, V.K. Jain and Neelam
}

Department of Veterinary Medicine, Lala Lajpat Rai University of Veterinary and Animal Sciences, Hisar - 125004, Haryana, India

*Corresponding author

\begin{abstract}
A B S T R A C T
\section{Keywords}

Buffaloes,

Haemato-

biochemical,

Gastrointestinal

tract, Atony

\section{Article Info}

Accepted:

04 February 2019

Available Online:

10 March 2019

The present study was planned to investigate haemato-biochemical alterations in buffaloes affected with gastrointestinal tract atony. The study was carried out in 50 clinical cases of non-traumatic, primary gastrointestinal tract atony in buffaloes. Eight apparently healthy buffaloes were included in the study which constituted the control group. Haematological alterations in buffaloes affected with atony of gastrointestinal tract revealed significant higher total leucocyte count, neutrophils and significantly lower lymphocytes than the apparently healthy buffaloes. The diseased buffaloes had significantly higher level of serum aspartate aminotransferase, total bilirubin, glucose, creatinine and total proteins levels along with significantly lower serum calcium, potassium and chloride levels than the buffaloes of control group. The present data may be utilized for suggesting therapeutic regimen for the treatment of animals affected with gastrointestinal tract atony.
\end{abstract}

\section{Introduction}

Productivity of dairy animals depends not only on good nutritious diet but also on its proper digestion and assimilation. An efficient digestive system is vital to an animal not only for its physical outlook but also to produce milk and meat (Walia et al., 2011). Being a ruminant, forestomach of buffalo has complex set of physiological and biochemical procedures to digest carbohydrate to produce volatile fatty acids. Subsequently these volatile fatty acids are absorbed by ruminal one (Radostits et al., 2006). Common symptoms of gastrointestinal tract atony are in mucosa. Normal reticulo-ruminal contraction is very much essential for proper digestion. Any deviation from these procedure lead to indigestion, which is followed by a common set of symptoms known as gastrointestinal motility disorders. Abnormalities of stomach and intestinal motility represent the most common consequence of gastrointestinal tract diseases. Disruption in gastrointestinal tract motility can result in hypermotility or atony, distension of segments of the tract, abdominal pain, dehydration and shock, out of which atony in gastrointestinal tract is commonest appetance to anorexia, dehydration, constipation, scanty or absence of feces, 
recurrent tympany, loss of production and body condition, suspended rumination, reduced or absence of ruminal motility, colic signs, sometimes fever etc. which not only affect the livestock itself but also affect the economic backbone of livestock farmers and thus the national economy (Radostits et al., 2006). Alterations in blood profile viz. haemoglobin $(\mathrm{Hb})$, Total erythrocytes count (TLC), Differential leucocyte count (DLC) has been reported due to the chronic irritation of the forestomach wall leading to malnutrition (Sethuraman and Rathore, 1979), and inflammation (Hailat et al., 1996). Due to the absorption of toxic products from the atonic alimentary tract, the cellular disturbances of liver occurs which is responsible for leakage of enzymes from hepatocytes resulting in increased levels of hepatic enzymes due to the disruption of hepatocytes (Hussain et al., 2013). Therefore, the present study was planned to investigate the haemato-biochemical alteration in buffaloes affected with gastrointestinal tract atony.

\section{Materials and Methods}

\section{Selection of animals}

The study was conducted in Department of Veterinary Medicine, College of Veterinary Sciences, Lala Lajpat Rai University of Veterinary and Animal Sciences (LUVAS), Hisar. Fifty buffaloes showing typical signs of primary gastrointestinal tract atony and were found negative during radiographic examination were included in this study. No faeces, scanty hard faeces with or without mucus, depression, dehydration, suspended rumination, distended abdomen and colic were main clinical signs. Eight apparently healthy buffaloes were also included in this study as a control group to compare the findings of diseased animals with apparently healthy animals.

\section{Clinical observations}

Clinical examination of the suspected animals was done for various parameters viz. rectal temperature, pulse rate, respiration rate and ruminal movements.

\section{Sampling}

Blood samples were collected aseptically from the jugular vein. Blood samples were collected in ethylenediamine-tetra acetic acid (EDTA) vial for haematological examination and in vials without anticoagulant for harvesting serum. Serum samples were stored at $-20^{\circ} \mathrm{C}$ in aliquots till analysis.

\section{Haematological parameters}

The whole blood samples were processed for estimation of Haemoglobin (Through spectrophotometrically using Drabkin's reagent); Packed cell volume (by microhaematocrit method) and Total leukocyte count (using a standard haemocytometer). Differential leucocyte count (DLC) was done through Giemsa staining of blood smear.

\section{Biochemical analysis}

The following serum biochemical parameters were estimated using Bayer Diagnostic Kit with the help of an RA50 Auto analyser. Various biochemical parameters viz. aspartate amino transferase, alaninine aminotransferase, total bilirubin, alkaline phosphatase, urea, creatinine, total proteins, albumin, glucose and calcium were estimated. Sodium, potassium and chloride levels were estimated by flame photometry (Hawk et al., 1954).

\section{Statistical analysis}

The data was subjected to one way ANOVA by using SPSS software, means and standard errors were calculated for comparison 
between control and animals with gastrointestinal tract atony. Significance level was $(\mathrm{p}<0.05)$

\section{Results and Discussion}

The present study was planned to investigate the alterations in haematological and biochemical parameters in animals suffering from gastrointestinal atony, to know the impact of gastrointestinal atony on blood profile, liver and kidney functions.

\section{Clinical vital parameters}

Clinical vital parameters are depicted in Table 1. The mean rectal temperature $\left(39.15 \pm 0.24^{\circ} \mathrm{C}\right)$ and respiration rate $(22.0 \pm 3.52$ per $\mathrm{min})$ did not differed significantly from the control group. Pearson and Pinsent (1977) and Kumar (2014) observed no change in respiration rate in cases of intestinal obstruction and Singh et al., (2001) proposed that increase in respiration rate might be due to increase in blood $\mathrm{pH}$ and $\mathrm{pCo}_{2}$ values. Heart rate (72.60土4.26per min) was significantly $(\mathrm{p} \leq 0.05)$ higher than the control group. Dennison et al., (2002) also observed tachycardia in cases of intestinal obstruction. Ruminal motility $(0.40 \pm 0.24$ per 2 min) was reduced significantly $(\mathrm{p} \leq 0.05)$ compared to the control value. The results were in agreement with the findings of Braun et al., (2012), where atony of rumen was reported in cases of intestinal obstruction. Rumen atony can be explained as high concentration of amines in rumen might have resulted in their increased flow to abomasum and possibly may leads to an increased gastrin secretion in these buffaloes which subsequently decreases ruminal motility (Hans Raj, 2005).

\section{Haematology}

Haematological findings are predicted in Table 2. The mean haemoglobin level and mean PCV level did not differ significantly from their respective control values. The mean TLC value $(8.65 \pm 0.38 \times 103 / \mu l)$ was significantly higher from the control value $(p \leq 0.05)$. The mean relative neutrophil count $(62.60 \pm 4.19 \%)$ was significantly $(\mathrm{p} \leq 0.01)$ higher than the control animals. Neutrophilia might have resulted from chronic irritation of the forestomach wall by impacted feed materials, leaving the wall exposed to secondary infection, which resulted in inflammation (Hailat et al., 1996). Whereas the mean relative lymphocyte count in diseased animals $(35.40 \pm 4.35 \%)$ was significantly $(\mathrm{p} \leq 0.05)$ lower than the control animals. Decreased lymphocytes could be due to release of corticosteroid as a result of stress (Jain, 1986).

\section{Biochemistry}

Serum biochemical parameters are depicted in Table 3. The AST activity (227.0 $\pm 36.78 \mathrm{IU} / \mathrm{L})$, and total bilirubin levels $(3.08 \pm 0.68 \mathrm{mg} \%)$ were significantly $(\mathrm{p} \leq 0.05)$ higher than the animals of control group. The significantly higher levels of AST and total bilirubin in diseased buffaloes are considered valuable guides in hepatic damage. Absorption of toxic products from the rumen or alimentary tracts, starvation and constipation leading to cellular disturbances of liver parenchyma and could have resulted in increased levels of AST and total bilirubin. Such hepatic damage could be due to anorexia and constipation that lead to absorption of toxic substances from the rumen and GIT (Hussain et al., 2013).

The mean glucose level (125.4 \pm 20.12$)$ was significantly $(\mathrm{p} \leq 0.05)$ higher than the control value. The stress of digestive disorders might have resulted in hyperglycaemia due to the glycogenolytic effect of released adrenocorticosteroids. The metabolic pattern of the diseased animal becomes disturbed owing to higher levels of blood glucose and such 
animals may utilize glucose rather than VFA for metabolism (Kaneko et al., 1997).

Urea level (83.16 \pm 22.23$)$ and mean creatinine level $(2.24 \pm 0.48)$ were significantly $(\mathrm{p} \leq 0.05)$ higher than the control animals. The observed elevation in serum creatinine and urea levels could be attributed to a decrease in renal blood flow as a part of compensatory mechanisms to maintain circulation in hypovolemia associated with dehydration, leading to azotemia. Increased creatinine and urea level could be correlated with anorexia, starvation, decreased rumeno-reticular activity and dehydration, as catabolism is accelerated under such conditions. The mean total protein level $(8.3 \pm 0.14 \mathrm{gm}$. \%) was significantly $(\mathrm{p} \leq 0.05)$ higher than their respective control levels. Hyperproteinaemia recorded in diseased animals might be due to dehydration, haemoconcentration and release of some positive acute proteins in response to acute inflammation or due to stress (Jain, 1986; Kaneko et al., 1997).

Similarly, in a recent study, it was found that both cattle and buffalo with omasal impaction had normal serum total protein levels with hypoalbuminemia and hyperfibrinogenemia compared with clinically healthy control animals (Hussain et al., 2013). The authors attributed those findings to the chronic starvation or failure of the liver to synthesize adequate amounts of proteins.

Table.1 Clinical vital parameters (mean $\pm \mathrm{SE}$ ) in buffaloes suffering from gastrointestinal tract atony

\begin{tabular}{|l|c|c|}
\hline Parameters & Control animals & Diseased animals \\
\hline Temperature $\left({ }^{\circ} \mathbf{C}\right)$ & $38.71 \pm 0.09$ & $39.15 \pm 0.24$ \\
\hline Heart rate (per min.) & $57.80 \pm 3.08^{\mathrm{a}}$ & $72.60 \pm 4.26^{\mathrm{b}}$ \\
\hline Respiration rate (per min.) & $16.20 \pm 1.60$ & $22.00 \pm 3.52$ \\
\hline Rumen motility (per 2 min.) & $4.20 \pm 0.29^{\mathrm{b}}$ & $0.40 \pm 0.24^{\mathrm{a}}$ \\
\hline
\end{tabular}

Means bearing different superscripts in a row differ significantly $(\mathrm{p}<0.05)$

Table.2 Haematological alteration in buffaloes affected with gastrointestinal tract atony

\begin{tabular}{|c|c|c|}
\hline Parameters & Control animals & Diseased animals \\
\hline $\mathrm{Hb}(\mathrm{g} / \mathrm{dl})$ & $10.59 \pm 0.3$ & $9.74 \pm 0.76$ \\
\hline $\mathrm{PCV}(\%)$ & $29.50 \pm 0.9$ & $27.40 \pm 4.84$ \\
\hline TLC $\left(10^{3} / \mu \mathrm{l}\right)$ & $5.29^{\mathrm{a}} \pm 0.53$ & $8.65^{\mathrm{b}} \pm 0.38$ \\
\hline Neutrophils $(\%)$ & $31.10^{\mathrm{a}} \pm 1.89$ & $62.60^{\mathrm{b}} \pm 4.19$ \\
\hline Lymphocytes $(\%)$ & $68.10^{\mathrm{b}} \pm 2.20$ & $35.40^{\mathrm{a}} \pm 4.35$ \\
\hline Eosinophils (\%) & $1.84 \pm 0.20$ & $1.40 \pm 0.87$ \\
\hline Monocytes $(\%)$ & $0.40 \pm 0.02$ & $0.60 \pm 0.04$ \\
\hline Basophils (\%) & $0.00 \pm 0.00$ & $0.00 \pm 0.00$ \\
\hline
\end{tabular}

Means bearing different superscripts in a row differ significantly $(\mathrm{p}<0.05)$ 
Table.3 Biochemical parameters (mean $\pm \mathrm{SE}$ ) of buffaloes suffering from gastrointestinal tract atony

\begin{tabular}{|c|c|c|}
\hline Parameters & Control animals & Diseased animals \\
\hline AST (IU/L) & $127.7^{\mathrm{a}} \pm 6.78$ & $227.0^{\mathrm{b}} \pm 36.78$ \\
\hline ALT $(\mathrm{IU} / \mathrm{L})$ & $128.8 \pm 7.13$ & $184.2 \pm 28.07$ \\
\hline ALP $(\mathrm{IU} / \mathrm{L})$ & $45.23 \pm 1.45$ & $49.47 \pm 1.59$ \\
\hline Total Bilirubin $(\mathrm{mg} / \mathrm{dl})$ & $0.33^{\mathrm{a}} \pm 0.09$ & $3.08^{\mathrm{b}} \pm 0.68$ \\
\hline Glucose $(\mathrm{mg} / \mathrm{dl})$ & $57.9^{\mathrm{a}} \pm 7.41$ & $125.4^{\mathrm{b}} \pm 20.12$ \\
\hline Urea $(\mathrm{mg} / \mathrm{dl})$ & $132.7^{\mathrm{a}} \pm 4.34$ & $183.58^{\mathrm{b}} \pm 5.47$ \\
\hline Creatinine $(\mathrm{mg} / \mathrm{dl})$ & $0.50^{\mathrm{a}} \pm 0.07$ & $2.24^{\mathrm{b}} \pm 0.48$ \\
\hline Total Protein $(\mathrm{g} / \mathrm{dl})$ & $7.26^{\mathrm{a}} \pm 0.17$ & $8.30^{\mathrm{b}} \pm 0.14$ \\
\hline Albumin $(\mathrm{g} / \mathrm{dl})$ & $3.74 \pm 0.17$ & $3.84 \pm 0.22$ \\
\hline Sodium $(\mathrm{mmol} / \mathrm{L})$ & $140.4 \pm 5.71$ & $121.80 \pm 3.35$ \\
\hline Potassium $(\mathrm{mmol} / \mathrm{L})$ & $5.46^{\mathrm{b}} \pm 0.24$ & $2.99^{\mathrm{a}} \pm 0.10$ \\
\hline Chloride $(\mathrm{mmol} / \mathrm{L})$ & $101.43^{\mathrm{b}} \pm 1.57$ & $81.98^{\mathrm{a}} \pm 3.35$ \\
\hline Calcium $(\mathrm{mg} / \mathrm{dl})$ & $11.74^{\mathrm{b}} \pm 0.34$ & $7.73^{\mathrm{a}} \pm 0.87$ \\
\hline Phosphorus $(\mathrm{mg} / \mathrm{dl})$ & $6.24 \pm 0.36$ & $5.80 \pm 0.22$ \\
\hline Magnesium $(\mathrm{mg} / \mathrm{dl})$ & $2.35 \pm 0.11$ & $2.73 \pm 0.10$ \\
\hline
\end{tabular}

Means bearing different superscripts in a row differ significantly $(\mathrm{p}<0.05)$

$\mathrm{ALT}=$ Alanine aminotransaminase; $\mathrm{AST}=$ Aspartate aminotransaminase; $\mathrm{APL}=$ Alkaline phosphatase

The mean calcium level $(7.73 \pm 0.87 \mathrm{mg} \%)$ was significantly $(p \leq 0.05)$ lower than the control value. Hypocalcaemia results in depression of smooth-muscle contractility and neuromuscular transmission, which in turn contributes to reduced gastrointestinal tract motility. Hypocalcaemia was observed in cases of haemorrhagic bowel syndrome (Braun et al., 2010), reticulo-ruminal atony (Hans Raj, 2005) and in intestinal obstruction (Kumar, 2014), and was probably caused by intestinal atony with no or reduced resorption of calcium.

The inorganic phosphorus level and sodium level did not differed significantly from their respective control values. The mean potassium level $(2.99 \pm 0.10 \mathrm{mmol} / \mathrm{L})$ and mean chloride level $(81.98 \pm 3.35 \mathrm{mmol} / \mathrm{L})$ were significantly $(\mathrm{p} \leq 0.05)$ lower than their respective control levels. Hypokalaemia observed in the diseased buffaloes could be due to fasting and adaptive response to continued hypo adrenocortical activity.
Hypokalaemia was also reported by Braun et al., (2010). Mild to moderate hypocalcaemia and hypokalaemia are the commonly identified abnormalities of indigestion encountered during prolonged anorexia (Smith, 2009). Potassium is involved in nerve and muscle excitability and in the water and acid-base balance (Underwood and Suttle, 1999). Hans Raj (2005) also reported hypokalaemia in clinical cases which may be attributed to its less availability as well as to the fact that animal body contains virtually no reserve of potassium. Stress also reported to be one of the factors responsible for hypokalaemia (Preston and Linser, 1985). An intracellular shift of potassium might have occurred subsequent to generation of metabolic alkalosis (Kaneko et al., 1997). Chloride is a major extracellular anion which maintains water and osmotic pressure and regulates acid-base balance in conjunction with sodium. In present study, hypochloraemia might be due to the longstanding anorectic status of the animals 
(Radostits et al., 2000). Hypochloremia was observed in cases of intestinal obstruction (Hammond et al., 1964 and Smith, 1985).

Buffaloes affected with gastrointestinal tract atony were found to be with changes in their haematological and biochemical parameters. Among haematological parameters, significant increase in TLC with neutrophilia and lymphopenia was found. Serum biochemical analysis revealed, increase in AST, ALP, urea, creatinine, glucose, total bilirubin level and decreased level of $\mathrm{Ca}^{+2}, \mathrm{~K}^{+}$ and $\mathrm{Cl}^{-}$. The findings of the present study may be utilised for suggesting therapeutic regimen for the treatment of animals affected with gastrointestinal tract atony.

\section{References}

Braun, U., Beckmann, C., Gerspach, C., Hassig, M., Muggli, E., Schweizer, G.K. and Nuss, K. 2012. Clinical findings and treatment in cattle with caecal dilatation. BMC Veterinary Research. 8:75.

Braun, U., Schmid, T., Muggli, E., Steininger, K., Previtali, M., Gerspach, C., Pospischil, A. and Nuss, K. 2010. Clinical findings and treatment in 63 cows with haemorrhagic bowel syndrome. Schweizer Archivfür Tierheilkunde. 152(11):515-522.

Dennison, A.C., Vanmetre, D.C., Callan, R.J., Dinsmore, P., Mason, G.L. and Ellis, R.P. 2002. Hemorrhagic bowel syndrome in dairy cattle: 22 cases (1997-2000). Journal of the American Veterinary Medical Association. 221:686-689.

Hailat, N., Nouth, S., Al-Darraji, A., Lafi, S., Al-Ani, F. and Al-Majali, A., 1996. Prevalence and pathology of foreign bodies (plastics) in Awassi sheep in Jordan. Small Ruminants Research. 24, 43-48.
Hammond, P.B., Dzuik, H.K., Usenik, E.A and Stevens, C.E. 1964. Experimental intestinal obstruction in calves. The Journal of Comparative Pathology and Therapeutics. 74: 210-22.

Hans Raj 2005. Clinical management of traumatic reticulo-peritonitis vis-à-vis mineral status and rumen biological dynamics in water buffaloes (Bubalus bubalis). PhD. Thesis, submitted to CCSHAU, Hisar, Haryana.

Hawk, P.B., Oser, B.L. and Summersion, W.H. 1954. Practical Physiological Chemistry. McGraw-Hill, New York. Pp. 1439.

Hussain, S.A., Uppal, S.K., Randhawa, C., Sood, N.K. and Mahajan, S.K. 2013. Clinical characteristics, hematology, and biochemical analytes of primary omasal impaction in bovines. Turkish Journal of Veterinary and Animal Sciences, 37(3):329-336.

Jain, N.C. 1986. Schalms Veterinary haematology. 4th edn. Lea and Febiger, Philadelphia, USA, 1168.

Kaneko, J.J., Harvey, J.W. and Bruss, M.L. 1997. Clinical Biochemistry of Domestic Animals, $5^{\text {th }}$ edn, (Academic Press, New York), 120-138

Kumar, A. 2014. Studies on ultrasonographic diagnosis and prognosis of intestinal obstruction in bovines. M.V.Sc. Thesis, submitted to G.D.V.A.S.U., Ludhiana.

Pearson, H. and Pinsent, P.J.N. 1977. Intestinal obstruction in cattle. The Veterinary Record.101:162-66.

Preston, R.L. and Linser, J.R. 1985. Potassium in animal nutrition. In: Potassium in Agriculture (Munson, R.D. ed.). American Society of Agronomy, Madison, Wisconsin, pp: 595-617.

Radostits, O.M., Gay, C.C., Blood, D.C. and Hinchcliff, K.W. 2000. Veterinary Medicine: A textbook of the diseases of cattle, horses, sheep, pigs and goats, 
$9^{\text {th }}$ edn. Saunders Company Ltd., $\quad$ S. and Singh, J. (ed) Ruminant Surgery. London. Pp. 183-224.

Radostits, O.M., Gay, C.C., Hinchcliff, K.W. and Constable, P.D. 2006. Veterinary Medicine E-Book: A textbook of the diseases of cattle, horses, sheep, pigs and goats. Elsevier Health Sciences.

Sethuraman, V. and Rathore, S.S. 1979. Clinical, haematological and biochemical studies in secondary in digestion in bovines due to traumatic reticulitis and diaphragmatic hernia. Indian Journal of Animal Science. 49: 703-706.

Singh, J., Singh, A. P. and Patil, D. B. 2001. The Digestive Sysytem. In: Tyagi R. P.

Smith, B.P. 2009. Large Animal Internal Medicine, fourth ed. Elsevier. USA. Pp. 779-870.

Smith, D. F. 1985. Bovine Intestinal Surgery. Part IV. Modified Veterinary Practices. 66:277-81.

Underwood, E.J. and Suttle, N.F. 1999. The mineral nutrition of livestock (3rd edn.) Wallingford, U.K. CABI, publishing. Pp. 185-212.

Walia, R., Ravikanth, K. and Maini, S. 2011. Efficacy of Ruchamax N in treatment of Digestive Disorders in Cow. Veterinary World, 4(3), p.126.

\section{How to cite this article:}

Jubin, Yudhbir Singh, V.K. Jain and Neelam. 2019. Investigations on Haemato-biochemical Alterations in Buffaloes Affected with Gastrointestinal Tract Atony. Int.J.Curr.Microbiol.App.Sci. 8(03): 7-13. doi: https://doi.org/10.20546/ijcmas.2019.803.002 